\title{
MAKNA NEGOSIASI POLITIK BAGI PEREMPUAN DI PARLEMEN
}

\author{
Indiska Handiana Mughni \\ Alumni Magister Ilmu Komunikasi Pascasarjana Unisba \\ e-mail : indiskahandiana93@gmail.com
}

\begin{abstract}
Abstrak. Saat ini negosiasi sudah tidak dianggap sebelah mata, negosiasi telah menjadi fenomena. Kehadiran perempuan dalam pembuatan dan pengambilan keputusan diharapkan dapat mendorong terjadinya sejumlah perubahan atas kebijakan yang diputuskan. Anggota DPRD perempuan masih relatif terbatas dalam memanfaatkan hak inisiatifnya untuk menyusun Rancangan Peraturan Daerah. Dari fenomena tersebut, maka penulis meneliti ini bertujuan untuk mengetahui bagaimana "Makna Negosiasi Politik bagi Perempuan di Parlemen". Penelitian ini yaitu menggunakan metode kualitatif dengan pendekatan fenomenologi. Teori yang digunakan dalam penelitian ini menggunakan Face-Negotiation Theory Ting-Toomey (1988). Teknik penentuan sampel yang digunakan adalah purposive sampling, yaitu pemilihan siapa subjek yang ada dalam posisi terbaik untuk memberikan informasi yang dibutuhkan. Untuk mendapatkan data penelitian menggunakan teknik observasi, studi kepustakaan, dan wawancara anggota perempuan DPRD Provinsi Jawa Barat. Menganalisis data yang sudah terkumpul maka penulis menggunakan teknik analisis data kualitatif. Berdasarkan hasil temuan dan analisis ditemukan bahwa terdapat beberapa kesamaan seperti makna negosiasi politik bagi perempuan di parlemen adalah untuk mendapatkan kesepakatan.
\end{abstract}

Kata Kunci : Makna, Negosiasi Politik, Anggota, Perempuan, Komunikasi, Parlemen, Dewan Perwakilan Rakyat Daerah Provinsi Jawa Barat

\begin{abstract}
Currently the negotiations is not considered one eye, the negotiations have become a phenomenon. The presence of women in decision-making and are expected to boost the number of changes on policy decisions. Members of Parliament women are still relatively limited in using the right of initiative to draw up a draft Regional Regulation. Review of the phenomenon, the authors of this research aims to determine whether to know how "Meaning of Political Negotiation for Women in Parliament". This research is using qualitative methods and approach phenomenology studies. Theory of this research used Face-Negotiation Theory Ting-Toomey (1988). The type of sampling used is Purposive Sampling, that the selection of a subject who is in the best position to provide the required information. For data collection techniques are used by Observation, library research and interview members of parliament women of the House of Representatives of West Java Province. Analyzing the data have been collected, the authors use qualitative data analysis techniques. Based on the findings and analysis it is found that there are some things like the meaning of negotiations for women who are having an agreement.
\end{abstract}

Key Words : Meaning, Political Negotiation, Women, Communication, Parliament, House of Representatives of West Java Province.

\section{Pendahuluan}

\section{a. Konteks Penelitian}

Saat ini negosiasi sudah tidak dianggap sebelah mata, negosiasi telah menjadi fenomena. Keterlibatan perempuan dalam proses pengambilan keputusan atau komunikasi negosiasi dengan pihak lain adalah sebuah sine qua non di dalam demokrasi. Negosiasi atau perundingan adalah proses untuk menghasilkan kesepakatan atau perjanjian diantara kedua pihak yang bermasalah. Aktivitas negosiasi merupakan bentuk pertemuan antara dua pihak atau lebih untuk mencapai suatu kesepakatan. Negosiasi memerlukan trik dan strategi karena pada dasarnya semua orang tidak mau kalah, semua orang tidak mau dipaksa dan ditindas. Oleh sebab itu, pilihan yang paling baik adalah bagaimana negosiasi dapat tercapai untuk menguntungkan kedua belah pihak. (Heryanto, 2013:105).

Sejumlah aktivitas negosiasi, misalnya, dalam proses penggabungan kepentingan politik mulai dari membuat kebijakan, koalisi, fusi, aliansi hingga konfederasi, memerlukan negosiasi. Begitu pun saat konflik, misalnya, saat konflik perbatasan sebuah negara, maka salah satu penyelesaian kasus seperti ini adalah melalui negosiasi. (Kuswandoro 2012). Berdasarkan fenomena negosiasi politik di Indonesia saat ini perempuan dinilai mempunyai posisi strategis sebagai obor dan pilar harapan 
mencapai tujuan bersama menjadi bagian dunia menuju 2030.

Perempuan berpartisipasi aktif (subjek) yang tidak sekedar menjadi objek pembangunan serta meningkatkan kemampuan kaum perempuan dalam kepemimpinan, untuk meningkatkan jumlah posisi tawar-menawar dan keterlibatan dalam setiap program pembangunan, baik sebagai perencana, pelaksana, maupun melakukan pemantauan dan evaluasi kegiatan.

Dewan Perwakilan Rakyat Daerah provinsi (disingkat DPRD provinsi) adalah lembaga perwakilan rakyat daerah yang berkedudukan sebagai unsur penyelenggara pemerintahan daerah provinsi. DPRD provinsi terdiri atas anggota partai politik peserta pemilihan umum yang dipilih melalui pemilihan umum. DPRD provinsi mempunyai fungsi legislasi, anggaran, dan pengawasan yang dijalankan dalam kerangka representasi rakyat di provinsi. Dalam melaksanakan tugas sebagai anggota legislatif akan berkaitan dengan komunikasi. Komunikasi yang dilaksanakan oleh pemerintah seperti legislatif ini antara lain mencakup seluruh kebijakan yang menyangkut kepentingan warga, upaya meningkatkan loyalitas dan integrasi nasional, penerapan aturan dan perundang-undangan untuk menjaga ketertiban dan kehormatan dalam hidup bernegara, dan mendorong terwujudnya partisipasi masyarakat dalam mencapai tujuan nasional. (Heryanto, 2010: 7).

Dalam hal ini pentingnya memahami negosiasi politik bagi para praktisi politik di parlemen, karena faktor negosiator dinilai sebagai faktor yang vital menentukan keberhasilan memenangkan persaingan di depan mata. Bagi kalangan feminisme, peningkatan representasi dalam politik menjadi sangat penting, karena representasi perempuan dalam parlemen membuka peluang terjadinya keadilan sosial dan juga ekonomi. Kehadiran perempuan dalam pembuatan dan pengambilan keputusan diharapkan dapat mendorong terjadinya sejumlah perubahan atas kebijakan yang diputuskan. Selain itu kepentingan perempuan dapat lebih terwakili dan mereka dapat mendukung berbagai kebijakan yang memberikan manfaat kepada masyarakat. Anggota DPRD perempuan masih relatif terbatas dalam memanfaatkan hak inisiatifnya untuk menyusun Rancangan Peraturan Daerah. Hal ini juga seperti yang dikatakan Yenni Wahid bahwa "peran pemberdayaan perempuan itu masih rendah dalam mengambil keputusan. Misalnya, dalam memilih hak bekerja atau tidak bekerja, bahkan di bangku parlemen perempuan masih sangat kurang mendapat tempat. Belum lagi terbentur masalah kultur dan sebagainya" Ungkap Yenni Wahid, Selasa (30/1).

Menurut pandangan Hannah Arent (dalam Hastanti Widy, 2010:331) masalah kuantitas bukanlah masalah penting, yang terpenting adalah tindakan politik apa yang dapat dilakukan dalam posisi itu. Untuk menjadi perencana, pelaksana dan pemantau pembangunan dalam menjalankan tugas legislasi maka potensi yang harus dimiliki oleh perempuan adalah memiliki kemampuan negosiasi politik dan kemauan serta kepedulian kepada masyarakat. Hal ini agar perempuan dapat terakses dalam berkompetensi dengan kaum laki-laki, oleh karena itu pemerintah mengeluarkan kebijakan sebagai wujud motivasi perempuan untuk aktif dalam partai politik berdasarkan UndangUndang No.31 Tahun 2002 pasal 2 yang menjelaskan bahwa porsi perempuan untuk duduk dalam berbagai bidang pembangunan $30 \%$ dari jumlah anggota.

Dari berbagai fenomena negosiasi politik yang dilakukan oleh perempuan pada kenyataannya, masuknya perempuan dalam bidang politik masih menemui banyak hambatan yang berimplikasi pada rendahnya keterlibatan perempuan dalam bidang politik. Apakah kegagalan perempuan di parlemen dalam politik lebih banyak dipengaruhi oleh adat dan stigma budaya atau faktor kemampuan diri perempuan tersebut dalam bernegosiasi yang menempatkan posisi perempuan bukan sebagai pemimpin publik. Jumlah anggota perempuan dalam pembuatan kebijakan dan hukum-hukum formal/publik negara Indonesia yang sangat minim untuk dapat mempengaruhi sistem. Perlunya negosiasi politik untuk mencapai hal 
tersebut, dimana harus dipahami juga bahwa proses negosiasi politik itu merupakan sebuah bergaining power (tawar-menawar kuasa) yang melibatkan skill atau keterampilan negosiasi dari berbagai pihak yang mencoba untuk mengajukan dan menerima komitmen guna membentuk pemahaman bersama. (Heryanto, 2013:111)

Berdasarkan latar belakang dan fenomena yang telah diuraikan, maka penulis tertarik untuk meneliti dan mengetahui lebih lanjut yang dituangkan dengan judul "Makna Negosiasi Politik Bagi Perempuan di Parlemen".

\section{b. Fokus Penelitian dan Pertanyaan Penelitian Fokus Penelitian}

Sesuai dengan pemaparan pada konteks penelitian di atas, maka fokus pada penelitian ini adalah :

"Bagaimana makna negosiasi politik bagi perempuan anggota Dewan Perwakilan Rakyat Provinsi Jawa Barat di parlemen?

\section{Pertanyaan Penelitian}

Berdasarkan fokus penelitian di atas maka peneliti mengidentifikasi masalah sebagai berikut :

1. Bagaimana aktivitas negosiasi politik perempuan anggota Dewan Perwakilan Rakyat Provinsi Jawa Barat di parlemen dalam membuat kebijakan?

2. Bagaimana motivasi untuk mengembangkan potensi negosiasi politik perempuan anggota Dewan Perwakilan Rakyat Provinsi Jawa Barat?

3. Faktor-faktor apa saja yang mempengaruhi keberhasilan dan kegagalan negosiasi politik bagi perempuan anggota Dewan Perwakilan Rakyat Provinsi Jawa Barat di parlemen?

\section{c. Tujuan Penelitian}

Berdasarkan fokus penelitian dan pertanyaan penelitian di atas maka peneliti memiliki tujuan penelitian untuk mengetahui sebagai berikut :

1. Aktivitas negosiasi politik perempuan anggota Dewan Perwakilan Rakyat Provinsi Jawa Barat di parlemen dalam membuat kebijakan.
2. Motivasi untuk mengembangkan potensi negosiasi politik perempuan anggota Dewan Perwakilan Rakyat Provinsi Jawa Barat.

3. Faktor-faktor yang mempengaruhi keberhasilan dan kegagalan negosiasi politik bagi perempuan anggota Dewan Perwakilan Rakyat Provinsi Jawa Barat di parlemen.

\section{Pembahasan}

\section{a. Kajian Pustaka}

Negosiasi adalah perangkat teknis, sebuah penjabaran dari komunikasi secara praktikal. Ia mencerminkan karakter komunikasi. Sebagaimana yang dikemukakan oleh Susanti Adi Nugroho (2009: 21), bahwa negosiasi ialah proses tawar-menawar untuk mencapai kesepakatan dengan pihak lain melalui proses interaksi, komunikasi yang dinamis dengan tujuan untuk mendapatkan penyelesaian atau jalan keluar dari permasalahan yang sedang dihadapi oleh kedua belah pihak.

Anggota parlemen sebagai trustee, dan sebagai pengemban "mandat". Perwakilan (representation) adalah konsep bahwa seorang atau suatu kelompok mempunyai kemampuan atau kewajiban untuk bicara dan bertindak atas nama suatu kelompok yang lebih besar. (David Olever dalam Heryanto, $2012: 103$ )

Aktivitas politik dalam praktiknya tidak akan bisa mengelak dari aktivitas negosiasi, karena saat membangun kesepahaman dan hubungan baik dengan pihak lain terkadang dilakukan melalui aktivitas negosiasi. Di era demokrasi elektoral ini dapat kita simpulkan bahwa daya tawar yang dilakukan oleh anggota parlemen dalam sebuah negosiasi politik hanya bersandar pada perolehan suara dan untuk membagi-bagikan kekuasaan. Dengan begitu koalisi pemerintahan yang akan berjalan selanjutnya tidak akan stabil dan akan penuh dengan konflik. Padahal kunci keberhasilan penyelenggaraan pemerintahan daerah adalah kemampuan DPRD dalam menjalankan tiga plus fungsi utamanya-legislasi, anggaran dan pengawasan, dan plus representasi-secara simultan, proporsional dan berkelanjutan. Di masa mendatang penting untuk memperkuat struktur dan kelembagaan DPRD melalui 3 
(tiga) agenda: (i) memperjelas dan memperkuat kedudukan DPRD sebagai badan legislatif; (ii) memperkuat kewenangan DPRD; dan (iii) memperkuat kapasitas DPRD dalam menjalankan fungsi-fungsinya. (Mahfud MD, 2017: 66)

Fenomena negosiasi politik perempuan di parlemen seluruh dunia saat ini, bahwa pada setiap tingkat sosio-politik merasa dirinya kurang terwakili dalam parlemen dan jauh dari keterlibatan dalam pengambilan keputusan. Bahkan secara sepintas, komposisi pengambil keputusan politik sekarang di berbagai wilayah memberikan bukti bahwa perempuan tetap menghadapi sejumlah kendala dalam mengartikulasikan serta menentukan kepentingannya. (Shvedova, dalam International IDEA (2002: 19))

Dalam penelitian ini yaitu untuk mengetahui makna negosiasi politik bagi perempuan di parlemen dalam membuat kebijakan. Untuk mengetahui makna negosiasi politik tersebut, maka fokus penelitian ini meliputi aktivitas negosiasi politik, motivasi untuk mengembangkan negosiasi politik, serta faktor keberhasilan dan kegagalan yang memengaruhi negosiasi politik di parlemen. Makna adalah hasil praktek penandaan, praktek yang membuat suatu hal bermakna sesuatu. Pemaknaan yang dilakukan para pihak yang terlibat dalam komunikasi, berada dalam koridor mencari kebenaran, melalui langkah-langkah kreatif dalam memberi makna. Pemaknaan terhadap fakta atau kenyataan, dilakukan dengan berbagai cara. Merujuk pada Muhadjir, metode pemaknaan ini meliputi empat cara yaitu terjemah, tafsir, ekstrapolasi, dan pemaknaan.

- Terjemah: merupakan upaya mengemukakan materi atau substansi yang sama dengan media yang berbeda; media tersebut mungkin berupa bahasa satu ke bahasa lain, dari verbal ke gambar dan sebagainya.

- Penafsiran: tetap berpegang pada materi yang ada lalu dicari latar belakangnya dan konteksnya agar dapat dikemukakan konsep atau gagasannya secara lebih jelas lagi.

- Ekstrapolasi: lebih menekankan kemampuan daya fikir manusia untuk menangkap hal-hal- yang berada di balik yang tersajikan. Materi yang tersajikan dilihat tidak lebih dulu dari tanda-tanda atau indikator bagi sesuatu yang lebih jauh lagi.

- Memberikan makna: merupakan upaya lebih jauh dari penafsiran dan mempunyai kesejajaran dengan ekstrapolasi. Pemaknaan lebih menuntut kemampuan integratif manusia dari segi indrawinya, daya fikirnya dan akal budinya. Sama seperti ekstrapolasi, materi yang tersajikan dilihat tidak lebih dari tanda-tanda atau indikator bagi sesuatu yang lebih jauh dibalik yang tersaji bagi ekstrapolasi terbatas dalam arti emperik, sedangkan pada pemaknaan dapat pula menjangkau yang etik dan yang transendental. (Muhadjir, 2000: 187 - 188)

Makna dari objek yang terdapat dalam dunia nyata dihasilkan melalui pengalaman individu dengan objek tersebut. Aliran konstruktivisme memahami bahwa konsep dari makna yang dihasilkan oleh individu dikonstruksi berdasarkan kumpulan pengetahuan (stock of knowledge) individu yang dipengaruhi oleh pengalaman-pengalamnnya. Realitas dari sebuah objek nyata merupakan keterkaitan individu terhadap objek tersebut (Bungin, 2008:3).

Menurut Schutz, cara mengkontruksikan makna di luar dari arus utama pengalaman ialah melalui proses tipikasi, termasuk membentuk penggolongan atau klasifikasi dari pengalaman. Jadi hal tersebut yang menentukan apa yang disebut Schutz sebagai "hubungan-hubungan makna" (meaning contexs) yang merupakan serangkaian kriteria yang mengorganisir pengalaman inderawi ke dalam suatu makna. Hubungan-hubungan makna yang teroganisir tersebut juga melalui proses tipikasi yang disebut dengam "kumpulan pengetahuan" (stock of knowledge). Dalam setiap konteks ruang, waktu dan historis, individu memiliki dan menerapkan pengetahuan (stock of knowledge) yang terdiri dari semua fakta, kepercayaan, prasangka dan aturan yang dipelajari dari pengalaman pribadi dan pengetahuan yang telah tersedia. Untuk menggambarkan keseluruhan tindakan seseorang Schutz mengelompokkannya 
dalam dua fase, yaitu: a) Because motives (Weil Motiv), yaitu tindakan yang merujuk pada masa lalu. Dimana, tindakan yang dilakukan oleh seseorang pasti memiliki alasan dari masa lalu ketika ia melakukannya. b) In-order-to-motive (Um-zu-Motiv), yaitu motif yang merujuk pada tindakan di masa yang akan datang. Dimana, tindakan yang dilakukan oleh seseorang pasti memiliki tujuan yang telah ditetapkan. (Little John, 1996: 2004).

Selain itu untuk mengetahui makna negosiasi politik bagi perempuan di parlemen dalam penelitian ini juga didasari landasan teori tradisi sosio-kultural. Pendekatan sosiokultural terhadap teori komunikasi menunjukkan cara pemahaman kita terhadap makna, norma, peran dan peraturan yang dijalankan secara interaktif dalam komunikasi. Tradisi sosio-kultural berdasar pada premis orang berbicara, mereka membuat dan menghasilkan kebudayaan. Kebanyakan dari kita berasumsi bahwa kata adalah refleksi atas apa yang benar ada. Teori linguistik ini berlawanan dengan asumsi bahwa semua bahasa itu sama dan kata hanya sarana netral untuk membawa makna. Bahasa sebenarnya adalah struktur dari persepsi kita akan realitas. Teori dalam tradisi ini mengklaim bahwa komunikasi adalah hasil produksi, memelihara, memperbaiki dan perubahan dari realitas. Dalam hal ini, tradisi sosio-kultural menawarkan membantu dalam menjembatani jurang pemisah budaya antara "kita" dan "mereka".

Dalam teori tradisi sosio-kultural sebuah pergerakan dalam sosiologi, berfokus pada caracara manusia membentuk makna dan susunan dalam masyarakat melalui percakapan, yakni sebagai berikut (Griffin, 2000:22-35):

1. Manusia membuat keputusan dan bertindak sesuai dengan pemahaman subjektif mereka terhadap situasi ketika mereka menemukan diri mereka.

2. Kehidupan sosial terdiri dari prosesproses interaksi dari pada susunan, sehingga terus berubah.

3. Manusia memahami pengalaman mereka malalui makna yang ditemukan dalam simbol-simbol dari kelompok utama mereka dan bahasa merupakan bagian penting dalam kehidupan sosial.
4. Dunia terbentuk dari objek-objek sosial yang memiliki nama dan makna yang ditentukan secara sosial.

5. Tindakan manusia didasarkan pada penafsiran mereka, dimana objek dan tindakan yang berhubungan dalam situasi yang dipertimbangkan dan diartikan. Diri seseorang merupakan sebuah objek yang signifikan dan layaknya semua objek sosial, dikenalkan melalui interaksi sosial dengan orang lain.

Mengetahui hal tersebut maka negosiasi atau perundingan adalah proses untuk menghasilkan kesepakatan atau perjanjian diantara kedua pihak yang bermasalah. Negosiasi memerlukan trik dan strategi karena pada dasarnya semua orang tidak mau kalah, semua orang tidak mau dipaksa dan ditindas. Oleh sebab itu, pilihan yang paling baik adalah bagaimana negosiasi dapat tercapai untuk menguntungkan kedua belah pihak. Seperti teori yang digunakan dalam penelitian ini yaitu teori negosiasi muka (TingToomey (1988)), mengenai pentingnya seseorang melakukan komunikasi negosiasi untuk membuat suatu kebijakan atau keputusan dan kekuasaan. Teori ini memiliki beberapa asumsi yang terdiri dari elemen sebagai berikut ini:

1. Identitas diri penting di dalam interaksi interpersonal, dan individu-individu menegosiasikan identitas mereka secara berbeda dalam budaya yang berbeda.

2. Manajemen konflik dimediasi oleh muka dan budaya.

3. Tindakan-tindakan tertentu mengancam citra diri seseorang yang ditampilkan (muka).

Tanpa memperdulikan keadaan atau kelompok yang terlibat, negosiasi paling tidak mempunyai 4 (empat) elemen, yakni :

1. Ada beberapa perselisihan atau pertentangan

2. Ada beberapa tahap saling ketergantungan diantara kelompok

3. Situasinya harus kondusif untuk mendapatkan kesempatan berinteraksi.

4. Ada beberapa kemungkinan untuk sepakat. 
Jika elemen-elemen tersebut tidak ada, maka komunikasi negosiasi tidak membawa hasil yang positif. Pada saat komunikasi negosiasi tersebut berhasil, maka setiap kelompok merasa diuntungkan dari hasil tersebut. Sebaliknya, jika mereka gagal maka konflik tersebut akan meningkat. Disinilah pentingnya perempuan dalam komunikasi perlu mengetahui makna negosiasi politik di Parlemen.

Pentingnya bagi anggota perempuan di legislatif ini memaknai negosiasi politik, agar kemampuan dalam berkoalisi di pemerintahan dapat mencapai tujuan sesuai yang diharapkan. Hal ini juga seperti yang dikemukakan oleh David Olever (dalam Heryanto, 2012 :103), perundingan adalah saling menyeimbangkan, kita tidak menangguhkan rekan kita dan memaksakan semua yang diinginkan. Dalam melakukan negosiasi politik ada proses tawarmenawar, dimana perempuan anggota parlemen ini harus bisa mempengaruhi lawan bicara, agar bisa mencapai suatu mufakat sesuai yang diharapkan. Adapun faktor-faktor yang dapat mempengaruhi persepsi interpersonal adalah sebagai berikut (Mc David dan Harari, 1968:173):

\section{Pengalaman}

Pengalaman mempengaruhi kecermatan persepsi, pengalaman dapat diperoleh melalui proses belajar formal dan rangkaian peristiwa yang pernah dihadapi.

2. Motivasi

Motivasi adalah kegiatan memberikan dorongan kepada seseorang atau diri sendiri untuk mengambil suatu tindakan yang dikehendaki. Jadi motivasi berarti membangkitkan motif, membangkitkan daya gerak, atau menggerakan seseorang atau diri sendiri untuk berbuat sesuatu dalam rangka mencapai suatu kepuasan atau suatu tujuan (Effendy, 1993: 69).

3. Kepribadian

- Pada persepsi interpersonal, orang mengenakan pada orang lain sifatsifat yang ada pada dirinya, yang tidak disenanginya merupakan orangyang selalu melakukan proyeksi dan orang tersebut merupakan orang yang tidak cermat menanggapi persona stimuli bahkan mengaburkan gambaran sebenarnya.

- Orang yang menerima dirinya apa adanya, orang yang tidak dibebani perasaan bersalah, cenderung menafsirkan orang lain lebih cermat. Begitu pula, orang yang tenang, mudah bergaul, dan ramah, cenderung memberikan penilaian positif pada orang lain disebut dengan leniency effect.

- Kepribadian otoriter (authoritarian personality). Sindrom kepribadian yang ditandai oleh ketegaran berpegang pada nilai-nilai konvensional, hasrat berkuasa yang tinggi, kekakuan dalam houngan interpersonal, kecenderungan melemparkan tanggungjawab pada sesuatu di luar dirinya, dan memproyeksikan sebab-sebab dari peristiwa yang tidak menyenangkan pada kekuatan di luar dirinya.

- Manusia secara sadar berusaha menampilkan dirinya kepada orang lain sebaik mungkin. Ini disebut dengan Erving Goffman sebagai self-presentation (penyajian diri) (Rakhmat, 2008: 91)

Negosiasi (politik) adalah komunikasi untuk meyakinkan lawan agar memenuhi keinginan komunikator (negosiator). Strategi yang efektif untuk meyakinkan lawan bahwa misinya adalah hal rasional dan untuk kepentingan semua adalah dengan berpijak pada dasar komunikasi politik dan mengenali kondisi lawan. Perlu "packaging" terhadap pesan yang hendak disampaikan dan harus jelas pula sasarannya. Packaging disini maksudnya bagaimana kebijakan politik negosiator itu mampu disampaikan kepada lawan dengan isi, medium dan kredibilitas dan public trust yang dibutuhkan.

Alasan penulis menggunakan teori negosiasi muka karena teori ini memiliki keterkaitan khusus dengan teori tradisi sosiokultural. Manusia menggunakan simbol-simbol yang berbeda untuk menamai objek. Teori negosiasi rupa memberikan sebuah dasar untuk 
memperkirakan bagaimana manusia akan menyelesaikan karya rupa dalam kebudayaan yang berbeda atau sebuah perluasan alami dari teori-teori tentang argumentasi. Rupa mengacu pada gambar diri seseorang dihadapan orang lain. Hal ini melibatkan rasa hormat, kehormatan, status, koneksi, kesetiaan, dan nilainilai lain yang serupa. Sedangkan karya rupa adalah perilaku komunikasi manusia yang digunakan untuk membangun dan melindungi rupa mereka serta untuk melindungi, membangun atau mengancam rupa orang lain. Ada 2 variabel cultural yang memengaruhi karya rupa yaitu kolektivisme individulisme dan jarak kekuasaan.

Sebagai komunikator politik, negosiasi yang efektif harus memperhatikan karakteristik lawan, sumberdaya lawan, dan lingkungan yang mendukung suksesnya negosiasi. Alur proses negosiasi itu merupakan sebuah bergaining power (tawar menawar kuasa) yang melibatkan skill atau keterampilan negosiasi dari berbagai pihak yang mencoba untuk menjauhkan dan menerima komitmen guna membentuk pemahaman bersama. Penelitian ini bermaksud untuk mengetahui makna negosiasi politik bagi perempuan di parlemen dalam membuat kebijakan.

\section{b. Metodologi Penelitian}

Penelitian ini menggunakan metode kualitatif, dimana pendekatan tersebut didesain untuk membantu mengelaborasi dan menjelaskan kompleksitas dari suatu fenomena (Ulhoi dan Neergaard, 2007:256). Dalam penelitian ini, peneliti menggunakannya untuk mengetahui dan menganalisis makna negosiasi politik bagi perempuan DPRD Provinsi Jawa Barat di parlemen, di mana data dari pengurus dan anggotanya dijadikan sebagai data pendukung.

Penelitian ini menggunakan pendekatan kualitatif. Pendekatan ini merupakan suatu proses penelitian dan pemahaman yang berdasarkan pada metodologi yang menyelidiki suatu fenomena sosial dan masalah yang terdapat pada kehidupan manusia. Dalam melakukan penelitiannya peneliti menggunakan jenis penelitian yang bersifat kualitatif deskriptif dengan metode atau pendekatan fenomenologi. Fenomenologi adalah studi yang mempelajari fenomena seperti penampakan, segala hal yang muncul dalam pengalaman kita, cara kita mengalami sesuatu, dan makna yang kita miliki dalam pengalaman kita. (Kuswano, 2009:22).

Dalam penelitian ini peneliti melakukan penelitian dengan pendekatan fenomenologi dengan paradigma konstruktivisme. Paradigma ini memandang ilmu sosial sebagai analisis sistematis terhadap socially meaningful action melalui pengamatan langsung dan terperinci terhadap pelaku sosial yang bersangkutan menciptakan, memelihara, dan mengelola dunia sosial mereka. (Hidayat, 2003: 3).

Subyek penelitian, adalah orang, tempat, atau benda yang diamati dalam rangka pembumbutan sebagai sasaran (Kamus Bahasa Indonesia, 1989: 862). Pada subjek penelitian ini dilakukan pada Ketua DPRD Provinsi Jawa Barat, pimpinan fraksi dan perempuan anggota Dewan Perwakilan Rakyat Daerah Provinsi Jawa Barat yang sudah diseleksi berdasarkan kebutuhan penelitian. Hal ini karena objek tersebut merupakan salah satu contoh keberhasilan politik perempuan dalam bernegosiasi di parlemen, dan relevan dengan pembahasan dalam penelitian ini.

Menurut (Supranto 2000: 21) obyek penelitian adalah himpunan elemen yang dapat berupa orang, organisasi atau barang yang akan diteliti. Adapun Obyek penelitian dalam tulisan ini mengenai makna negosiasi politik bagi perempuan di parlemen dalam membuat kebijakan, yang meliputi: (1) Aktivitas perempuan di parlemen (2) motivasi untuk mengembangkan negosiasi politik (3) faktorfaktor keberhasilan dan kegagalan yang memengaruhi negosiasi politik perempuan anggota Dewan Perwakilan Rakyat Provinsi Jawa Barat dalam memaknai negosiasi politik, dan pengalamannya untuk membuat kebijakan sesuai tujuan yang diharapkan di parlemen.

Subjek penelitian menjadi informan yang akan memberikan berbagai informasi yang diperlukan selama proses penelitian informan dari penelitian ini ditentukan melalui suatu teknik yang diharapkan dapat memenuhi kriteria informan yang dibutuhkan yakni menggunakan Purposive Sampling. Purposive Sampling adalah: "Pemilihan sampel purposive atau bertujuan, kadang-kadang disebut sebagai judgement sampling, merupakan pemilihan siapa 
subjek yang ada dalam posisi terbaik untuk memberikan informasi yang dibutuhkan. Menentukan subjek atau orang-orang terpilih harus sesuai dengan ciri-ciri khusus yang dimiliki oleh sampel itu" (Moleong, 2007: 25).

\section{c. Hasil Penelitian}

Dalam menggali Makna Negosiasi Politik bagi Perempuan di Parlemen, peneliti melakukan wawancara mendalam dengan para informan yang merupakan Ketua DPRD Provinsi Jawa Barat, Pimpinan Fraksi, dan Anggota Perempuan DPRD Provinsi Jawa Barat yang tergolong pada kriteria perempuan di parlemen berdasarkan observasi yang peneliti tentukan. Peneliti berupaya menggali jawaban spontan melalui proses wawancara mendalam. Tema yang digulirkan seputar kegiatan atau aktivitas sehari-hari, latar belakang keluarga dan profesi, dan makna serta pengalamanpengalaman hidup. Dari jawaban mereka tergali sejumlah pernyataan penting informan yang dapat dianalisis pada langkah berikutnya.

Berdasarkan wawancara bersama para informan baik secara formal maupun informal di beberapa kesempatan seperti rapat dan kunjungan kerja maupun pertemuan insedentil dengan informan di tempat-tempat lainnya, diperoleh jawaban-jawaban yang didasarkan atas pengalaman, perasaan, maupun pemikiran mereka secara spontan. Terhadap jawabanjawaban tersebut, peneliti mereduksi jawabanjawaban yang tidak relevan dan mengumpulkan sejumlah pernyataan penting yang terkait dengan Makna Negosiasi Politik bagi Perempuan di Parlemen.

Berdasarkan temuan dan analisis, terjadi penegasan dimana pemaknaan negosiasi politik bagi perempuan di parlemen yang menjadi informan dalam penelitian ini memiliki pemaknaan yang berbeda-beda namun hampir sama, yakni yang memunculkan adanya idealis dan realistis pada posisi yang saling bertentangan satu dengan lainnya. Pandangan individu adalah mengenai pengalaman tentang objek, peristiwa, atau hubungan-hubungan yang diperoleh dengan menyimpulkan informasi dan menafsirkan pesan. Dalam melakukan negosiasi politik untuk mencapai kesepakatan ini idealisnya perempuan anggota DPRD Provinsi Jawa Barat sangat berpegang teguh pada ideologi-ideologi tertentu yakni peraturan perundang-undangan yang ada untuk kesejahteraan rakyat. Ideologi berkenaan dengan kumpulan ide atau gagasan. Menurut Mazhab Frankfurt, ideologi adalah struktur pengetahuan yang punya solusi terhadap problem konkret yang dihadapinya. (dalam Geuss, 1989: 1). Sedangkan realistis yaitu cara berpikir yang penuh perhitungan dan sesuai dengan kemampuan, sehingga gagasan yang akan diajukan bukan hanya angan-angan atau mimpi belaka tetapi adalah sebuah kenyataan.

Dimana perempuan anggota DPRD Provinsi Jawa Barat ini dalam membuat sebuah kebijakan dan keputusan sangat dipengaruhi oleh kebijakan pemerintah pusat, yang akhirnya antara apa yang diprogramkan kadang berbeda dengan yang diimplementasikan. Hal ini yang menjadi suatu keputusan yang harus disepakati bersama untuk mencapai kesejahteraan rakyat khususnya di Provinsi Jawa Barat. Makna lain yang terungkap adalah pengalaman perempuan diperlukan dalam kehidupan politik, hal ini untuk meningkatkan kemampuan negosiasi politik dalam membuat sebuah kebijakan, menyelesaikan permasalahan, yang mencapai suatu kesepakatan bersama sesuai yang diharapkan. Berdasarkan tujuan penelitian yang telah dibahas sebelumnya, maka dalam pembahasan ini peneliti membagi menjadi tiga bagian pembahasan, sebagai berikut:

\section{Aktivitas Negosiasi Politik Perempuan Anggota DPRD Provinsi Jawa Barat di Parlemen dalam Membuat Kebijakan}

Berdasarkan hasil temuan dan analisis ditemukan bahwa aktivitas negosiasi politik perempuan anggota DPRD Provinsi Jawa Barat hampir sama yaitu dapat dilihat dari tugas sebagai anggota DPRD yakni legislasi, penganggaran, dan pengawasan. Hal ini meliputi rapat pimpinan, rapat banmus, rapat pansus, rapat paripurna, dan reses. Dalam rapat-rapat tersebut yakni membahas dan membuat kebijakan Undang-undang, Raperda, Anggaran, LKPJ, penganggaran, dan lain sebagainya. Keterlibatan para informan dalam rapat-rapat yang dilaksanakan, merupakan sarana yang dapat dimanfaatkan dalam menyampaikan aspirasi masyarakat. Dari rapat-rapat tersebut juga menjadi suatu penentu keputusan untuk 
dijadikan peraturan daerah. Aktivitas negosiasi politik selalu terkait dengan kuadran apa yang dimainkan. Memilih kuadran negosiasi artinya memilih proses seperti apa yang hendak diutamakan dalam pencapaian tujuan tertentu dalam proses negosiasi. Paling tidak ada empat kuadran negosiasi yang lazimnya, yakni kuadran kolaborasi, dominasi, akomodasi, dan kompromi. (Heryanto, 2013: 106).

\section{Motivasi untuk Mengembangkan Potensi Negosiasi Politik Perempuan Anggota DPRD Provinsi Jawa Barat}

Beragam latar belakang yang membentuk mereka melibatkan diri dalam ranah politik praktis dan tetap eksis, tidak terlepas karena adanya motivasi atau motif yang mendasari informan dalam menggeluti dunia politik. Motivasi tersebut sebagai faktor-faktor yang ada dalam diri individu politisi perempuan yang menjadi subyek dalam penelitian ini. Dimana hal ini akan memengaruhi dan mendasari tindakan yang dilakukan, yang berlangsung melalui proses berfikir secara sadar disadari oleh para informan untuk mengembangkan potensi negosiasi politik di parlemen.

Berdasarkan hasil penelitian terhadap 5 orang politisi perempuan di DPRD Provinsi Jawa Barat, menunjukkan adanya motif informan terhadap dorongan untuk mengembangkan potensi negosiasi politiknya di parlemen. Dorongan yang muncul dari dalam diri sendiri sebagai dorongan yang kuat dengan segala eksistensinya yang melekat di dalamnya, serta dorongan yang muncul dari luar yang ternyata tidaklah sekuat dorongan yang muncul dari dalam diri sendiri. Hal ini akan membawa suatu konsekuensi yang nyata terhadap semangat, niat yang sungguh-sungguh dan ambisi masing-masing politisi perempuan dalam setiap aktivitas selama masa rangkaian kinerja di DPRD Provinsi Jawa Barat mulai dari 20092014 dan 2014-2019. Jika ditinjau dari motif yang melatarbelakangi (because motif) informan untuk mengembangkan potensi negosiasi politiknya di parlemen, peneliti mendapatkan jawaban yang beragam, yaitu datang dari masyarakat, dukungan keluarga, konstituen dan partai, serta panggilan jiwa sebagai aktivis, dan keinginan terlibat dalam mengambil suatu keputusan serta kebijakan.

3. Faktor-Faktor yang Mempengaruhi Keberhasilan dan Kegagalan Negosiasi Politik bagi Perempuan Anggota DPRD Provinsi Jawa Barat di Parlemen

Berdasarkan hasil temuan dan analisis, bahwa faktor-faktor yang memengaruhi keberhasilan dan kegagalan negosiasi politik bagi perempuan anggota Dewan Perwakilan Rakyat Provinsi Jawa Barat di parlemen dapat dibagi menjadi dua bagian yakni dari faktor internal personal, dan eksternal interpersonal. Internal personal ini adalah dari perbedaan latar belakang kebudayaan yang mempengaruhi pola pemikiran dan kemampuan negosiasi. Perbedaan individu yang meliputi perbedaan pendirian dan perasaan, perbedaan kepentingan antara individu dan kelompok yaitu baik ketataran sesama anggota parlemen di DPRD Provinsi Jawa Barat. Ekternal interpersonal adalah faktor dari masyarakat yakni budaya dan keadaan daerah satu berbeda dengan yang lainnya, dan kebijakan dari pemerintah pusat. Ini akhirnya menjadi sebuah bergaining power (tawar-menawar kuasa) yang melibarkan skill atau keterampilan negosiasi dari berbagai pihak yang mencoba untuk mengajukan dan menerima komitmen guna membentuk pemahaman bersama. (dalam Heryanto, $2013: 111$ ).

Berdasarkan hasil temuan dan analisis ditemukan bahwa adanya kendala-kendala politik yang dihadapi perempuan, yakni:

- Kurangnya dukungan partai, seperti terbatasnya dukungan dana bagi kandidat perempuan, terbatasnya akses untuk jaringan politik, dan meratanya standar ganda;

- Kurangnya hubungan dan kerja sama dengan organisasi publik lainnya, seperti serikat dagang (buruh) dan kelompokkelmopok perempuan;

- Tiadanya sistem pelatihan dan pendidikan yang dibangun dengan baik, bagi kepemimpian perempuan pada umumnya, maupun bagi orientasi 
perempuan muda pada kehidupan politik khususnya.

Jika ditinjau dari faktor-faktor yang memengaruhi keberhasilan dan kegagalan negosiasi politik perempuan anggota DPRD Provinsi Jawa Barat yaitu hampir sama, yakni:

a) Faktor keberhasilan yang memengaruhi negosiasi politik di parlemen yaitu memperjuangkan apa yang menjadi kewenangan dan kewajiban sebagai anggota legislatif, membuka komunikasi terbuka dengan sesama anggota dan masyarakat, memahami dan menguasai materi yang dinegosiasikan, mengetahui dan mempersiapkan strategi, mempunyai prinsip, pintar, dan belajar psikologis agar memahami situasi dan kondisi untuk melakukan negosiasi politik.

b) Faktor-faktor yang memengaruhi kegagalan negosiasi politik di parlemen yaitu adanya kekuasaan dan tekanan kebijakan dari pemerintah pusat, hambatan dari laki-laki anggota DPRD dan ketidaksetujuan masyarakat, lawan bicara yang merasa lebih pintar, dan adanya stigma adat budaya bahwa perempuan bukan sebagai pemimpin publik, dekadensi moral, kedekatan (conguisme), serta karakter dari pihak lain yang tidak bisa dipercaya, amanah dan jujur.

Dari penjelasan para 5 informan dalam penelitian ini tentang pemaknaan negosiasi politik bagi perempuan di DPRD Provinsi Jawa barat, menunjukkan bahwa informan memiliki pemaknaan yang berbeda-beda namun hampir sama. Perbedaan pemaknaan pada dasarnya dipengaruhi oleh keunikan secara berfikir, latar belakang individu, pengalaman masa lalu dan pemahaman politisi perempuan yang kemudian diinterpretasikan secara berbeda dalam mengkonstruksi makna negosiasi politik bagi perempuan di parlemen. Yang dimaksudkan sebagaimana telah diuraikan sebelumnya, maka digambarkan pada tabel di bawah ini:

Dengan demikian tujuan dari negosiasi politik ini adalah tercapainya kata-kata sepakat (gentlemen agreement) yang didalamnya terkandung kesamaan persepsi, saling pengertian dan persetujuan. Manfaatnya yaitu tercapainya jalinan kerja sama antarinstitusi maupun perorangan untuk melakukan suatu kegiatan atau usaha bersama atas dasar saling pengertian.

Makna negosiasi politik ini bisa dikonstruksi oleh cara pandang perempuan di DPRD Provinsi Jawa Barat. Sangat mungkin, kesepakatan berorientasi hasil akhir (goal oriented) dan terlepas dari peraturan perundangundangan, seolah-olah sahih dan menjadi realitas obyektif. Kita menyadari, bahwa realitas obyektif merupakan suatu kompleksitas definisi realitas (termasuk cara pandang dan keyakinan) serta rutinitas tindakan yang telah mapan terpola. Secara umum, dihayati oleh individu sebagai fakta. Dapat dikatakan bahwa manusia sebagai individu dalam lingkungan organisasi secara aktif menentukan konstruksi makna yang ada dalam lingkungannya sendiri, baik itu definisi perilaku manusia sebagai objek sosial maupun makna benda sebagai objek fisik.

Dengan demikian dapat disimpulkan bahwa makna negosiasi politik bagi perempuan di parlemen adalah komunikasi yang dilakukan secara intensif yang merupakan suatu karakter untuk berbicara benar dalam memberikan kontribusi menggoalkan ide dan gagasan, dari yang tadinya tidak sepakat menjadi sepakat, yang alot menjadi lunak, yang tidak berhasil (deadblock) menjadi ada titik temu yang akhirnya mencapai mufakat bersama. Pentingnya memahami negosiasi politik bagi para perempuan di parlemen, karena faktor negosiator dinilai sebagai faktor yang vital menentukan keberhasilan memenangkan persaingan di depan mata. Kehadiran perempuan dalam pembuatan dan pengambilan keputusan diharapkan dapat mendorong terjadinya sejumlah perubahan atas kebijakan yang diputuskan. Selain itu kepentingan perempuan dapat lebih terwakili dan mereka dapat mendukung berbagai kebijakan yang memberikan manfaat kepada masyarakat. 


\section{Penutup}

\section{a. Simpulan}

Berdasarkan hasil penelitian mengenai kontruksi makna negosiasi politik bagi perempuan di parlemen, studi fenomenologi politisi perempuan di DPRD Provinsi Jawa Barat, maka peneliti menemukan kesimpulan khusus sebagai berikut:

1) Aktivitas negosiasi politik perempuan anggota DPRD Provinsi Jawa Barat dalam membuat kebijakan hampir sama yaitu dapat dilihat dari tugas sebagai anggota DPRD, yakni rapat pansus, BanMus, rapat paripurna, baik itu dalam pembahasan Raperda, Anggaran, LKPJ, dan lain sebagainya, lalu reses terjun langsung ke lapangan, penganggaran dan pengawasan.

2) Motivasi untuk mengembangkan potensi negosiasi politik yaitu datang dari masyarakat, dukungan keluarga, konstituen, partai, serta keinginan diri terlibat dalam mengambil suatu keputusan dan kebijakan. Motivasi untuk mengembangkan potensi negosiasi politik ini juga dengan membangun kemampuan diri dan karakter yang memiliki mentalitas dan disiplin yang kuat. Pentingnya memiliki niat yang lurus dengan ingat pada Allah, bertanggungjawab, rajin dalam semua kegiatan atau aktivitas di parlemen, selalu berdoa, pantang menyerah dan ikhtiar yang maksimal.

3) Faktor-faktor yang memengaruhi keberhasilan negosiasi perempuan di parlemen yaitu; a. Memperjuangkan apa yang menjadi kewenangan dan kewajiban sebagai anggota legislatif, b. Membuka komunikasi dengan masyarakat, c. Memahami dan menguasai materi yang dinegosiasikan, d. Mengetahui dan mempersiapkan strategi, e. mempunyai prinsip, pintar, dan belajar psikologis agar memahami situasi dan kondisi untuk melakukan negosiasi politik. Adapun faktor-faktor yang memengaruhi kegagalan negosiasi politik perempuan di parlemen yaitu; a. Adanya kekuasaan dan tekanan kebijakan dari pemerintah pusat, b. hambatan dari laki-laki anggota DPRD dan ketidaksetujuan masyarakat, c. Lawan bicara yang merasa lebih pintar, d. Adanya stigma adat budaya bahwa perempuan bukan sebagai pemimpin publik, serta dekadensi moral, e. Kedekatan (conguisme), serta karakter dari pihak lain yang tidak bisa dipercaya, amanah dan jujur.

Berdasarkan kesimpulan umum bahwa makna negosiasi politik bagi perempuan di parlemen adalah komunikasi yang dilakukan secara intensif yang merupakan suatu karakter untuk berbicara benar dalam memberikan kontribusi menggoalkan ide dan gagasan, dari yang tadinya tidak sepakat menjadi sepakat, yang alot menjadi lunak, yang tidak berhasil (deadblock) mejadi ada titik temu yang akhirnya mencapai mufakat bersama.

\section{b. Saran-Saran}

Berdasarkan hasil penelitian tentang makna negosiasi politik bagi perempuan di parlemen DPRD Provinsi Jawa Barat, peneliti mengajukan rekomendasi (saran-saran), baik rekomendasi teoritis maupun praktis, yang kesemuanya mengacu pada Kegunaan Penelitian sebagaimana dikemukakan pada Bab Pendahuluan.

\section{Saran-saran Teoritis}

- Disarankan bagi peneliti lain selanjutnya agar dapat melakukan penelitian lebih mendalam terhadap makna negosiasi politik khususnya bagi perempuan di Lembaga parlemen dalam membuat kebijakan.

- Bagi peneliti selanjutnya disarankan menggunakan teori yang lebih mendalam untuk variable negosiasi politik.

\section{Saran-saran Praktis}

- Sebaiknya DPRD Provinsi Jawa Barat diberikan otonom dalam membuat kebijakan oleh pemerintah pusat, hal ini untuk 
mempermudah dalam menurunkan program sesuai peraturan perundang-undangan untuk mensejahterakan rakyat.

- Sebaiknya antara kebijakan yang dibuat sesuai dengan yang diimplementasikan di lapangan, hal ini agar apa yang telah dinegosiasikan dapat memberikan banyak manfaat pada masyarakat.

- Dari hal tersebut diatas disarankan politisi perempuan hendaknya merekonstruksi motif yang mendasari keterlibatannya di ranah publik. Motif sebagai anggota DPRD hendaknya tidak hanya sebatas sebagai ajang pembuktian kemampuan menembus ranah publik semata, tetapi sejatinya diaktualisasikan melalui kinerja, dedikasi dan loyalitas yang optimal dan kapabel dalam melaksanakan fungsi dan tugasnya dengan kinerja yang nyata untuk mensejahterakan rakyat.

- Pentingnya memahami negosiasi politik bagi para praktisi politik di parlemen, karena faktor negosiator dinilai sebagai faktor yang vital menentukan keberhasilan memenangkan persaingan di depan mata.

- Memaksimalkan kinerja dengan pandangan yang objektif dalam membuat kebijakan yang bermanfaat bagi masyarakat banyak, dan semakin menunjukkan kredibilitas dengan kinerja yang baik dan professional yang dimiliki dan percaya diri.

\section{Daftar Pustaka}

Anthony, Robert. 2008. Teknik Persuasi yang Efektif. Jakarta: Karisma

Ardianto, Elvinaro. 2010. Metode Penelitian untuk Public Relations Kuantitatif dan Kualitatif. Bandung: Simbiosa Rekatama Media.

Awaludin, Hamid. 2008. Damai Di Aceh: Catatan Perdamaian RI-GAM Di Delsinki. Yogyakarta: Centre For Strategic and International Studies

Berger, Peter L. dan Thomas Luckmann. 1966. The Social Construction of Reality: A Treatise in the Sociology of Knowledge. New York: Anchor Books.

Bungin, Burhan. 2007. Penelitian Kualitatif: Komunikasi, Ekonomi, Kebijakan, Publik dan Ilmu Sosial. Jakarta: Kencana Prenada Media Group.

Bungin, Burhan. 2008. Sosiologi Komunikasi, Teori, Paradigma dan Diskursus Teknologi Komunikasi di Masyarakat. Jakarta: Kencana Prenada Media Group

Dan Nimmo. 2005. Komunikasi Politik: Komunikator, Pesan, dan Media. Bandung: Rosdakarya

Finer, S.E. 1974. Comparative Government. England: Penguin Books Ltd. Hartmonds Worth.

Geuss, Raymond. 1989. The Idea of a Critical Theory, Habermas \& the Frankfurt School. Cambridge: Cambridge University Press.

Griffin, EM. 2012. A First Look at Communication Theory (8th edition). New York : Mc Graw-Hill

Hakim, Aziz Abdul. 2011. Hakim Negara Hukum dan Demokrasi Di Indonesia. Yogyakarta: Pustaka Pelajar

Harry, Eko Susanto. 2016. Komunikasi \& Gerakan Perubahan Kemajemukan Dalam Konstelasi Sosial, Ekonomi, Politik. Jakarta: Penerbitan Mitra Wacana Media

Hermawan, Herry. 2011. Reading Kit (Slide Presentation) Mata Kuliah Diplomasi dan Negosiasi. Jakarta: MIKOM Pasca Sarjana Univ. Muhammadiyah 
Heryanto, Gun Gun \& Irwa Zarkasy. 2012. Public Relations Politik. Bogor: Ghalia Indonesia

Heryanto, Gun Gun. 2010. Komunikasi Politik di Era Industri Citra. Jakarta: PT. Lasswell Visitama

Heryanto, Gun Gun. 2011. Dinamika Komunikasi Politik. Jakarta: PT. Lasswell Visitama

Heryanto, Gun Gun. 2013. Komunikasi Politik: Sebuah Pengantar. Bogor: Ghalia Indonesia

Hidayat, Komarudin, \& Azyumardi Azra. 2010. Pendidikan Kewarganegaraan: Demokrasi Hak Asasi Manusia dan Masyarakat Madani. Jakarta: Kencana Prenada Media Group

Irianto, Sulistyowati. 2006. Perempuan dan Hukum: Menuju Hukum yang Berspektif Kesetaraan dan Keadilan. Jakarta: Yayasan Obor Indonesia

Karras, Chester L. 1970. The Negotiating Game: How to get what you want. New York: Thomas Y. Crowell Company

Kuswarno, Engkus. 2009. Metode Penelitian Komunikasi Fenomenologi. Bandung: Widya Padjadjaran

Kuswandoro, Wawan E. 2008. Demokrasi Lokal. Surabaya: Insecs Publishing

Kuswandoro, Wawan E. 2012. Negotiation and Lobbying Skills. Surabaya: Insecs Publishing

Laode, Ida. 2008. Menegaskan Posisi Dewan Perwakilan Daerah, dalam Gagasan Amandemen UUD 1945 Suatu Rekomendasi. Jakarta: Komisi Hukum Nasional RI

Laski, H. J. 1947. The State in Theory and Practice. New York: The Viking Press.

Lenin, V. I. 1932. State and Revolution. New York: Internasional Publisher.

Lewicki, Roy J., BRUCE Barry, David M. Saunders, John W. Minton. 2003. Negotiation: $4^{\text {th }}$ Edition. New York: McGraw-Hill/Irwin

Lewicki, Roy J., Joseph A. Litterer. 1985. Negotitation. USA: Richard D. Irwin, Inc.
Littlejohn, SW \& Karen A. Foss. 2011. Teori Komunikasi (edisi ke-9). Jakarta : Salemba Humanika

L.Tubbs, Stewart \& Sylvia Moss. 1994. Human communication. Bandung: Remaja Rosdakarya

Mahfud MD, Moh. 2007. Perdebatan Hukum Tata Negara Pasca Amandemen Konstitusi. Jakarta: LP3ES

Manan, Bagir. 2004. Teori dan Poltiik Konstitusi. Bandung: FH UII Press

Morissan. 2013. Teori Komunikasi Individu Hingga Massa. Jakarta : Kencana

Mufti, Muslim. 2013. Teori-Teori Politik.

Bandung: CV. Pustaka Setia

Mufti, Muslim, \& Didah Durrotun N. 2013. Teori-Teori Demokrasi. Bandung: CV Pustaka Setia

Mulyana, Deddy. 2013. Komunikasi Politik: Membedah Visi dan Gaya Komunikasi Praktisi Politik. Bandung: PT. Remaja Rosdakarya

Nasroen, P. M. 1986. Ilmu Perbandingan Pemerintahan. Jakarta: Aksara Baru.

Nasution, Johan Bahder. 2011. Negara Hukum dan Hak Asasi Manusia. Bandung: CV. Mandar Maju

Nindito, Stefanus. 2005. Jurnal. Fenomenologi Alfred Schutz: Studi Tentang Kontruksi Makna dan Realitas dalam Ilmu Sosial. Universitas Atma Jaya Yogyakarta. Volume 2 Nomer 1. Juni

Noor, Juliansyah. 2011. Metode Penelitian. Jakarta: Kencana Prenada Media Group.

Nurudin. 2007. Sistem Komunikasi Indonesia. Jakarta: PT. RajaGrafindo Persada

Pamudji, S. 1994. Perbandingan Pemerintahan. Jakarta: Bumi Akasara.

Palar, Alvin dan Alumni. 2000. Penghapusan Diskriminasi Terhadap Wanita. Bandung: Penerbit Alumni

Partao, Zainal Abidin. 2006. Teknik Lobi dan Diplomasi Untuk Insane Public Relations. Jakarta: Gramedia

Rahardiansah, Trubus P. 2006. Pengantar Ilmu Poltiik: Konsep Dasar, Paradigma dan Pendekatannya. Jakarta: Universitas Trisakti 
Riharjo Budi I. 2011. Memahami Paradigma Penelitian Non-Positivisme dan Implikasinya. vol. 8 No. 1-oktober 2011:128-146.

Sahid, Komarudin. 2011. Memahami Sosiologi Politik. Bogor: Ghalia Indonesia

Schutz, Alfred. 1972. The Phenomenology of the Social Word. London: Heinemann Educational Book

Sobur, Alex, 2004. Semiotika Komunikasi. Bandung: Remaja Rosdakarya.

Soekanto, Soerjono. 1990. Sosiologi Suatu Pengantar, Edisi Baru Keempat. Jakarta: PT. RajaGrafindo Persada.

Soltau, R. F. 1961. An Introduction to Politics. London: Longmans.

Strong, $\quad$ C.F. $1960 . \quad$ Modern Political Constitutions. London: Sidgwick and Jackson Ltd.

Sunarto, K. 2004. Pengantar Sosiologi. Jakarta: Lembaga Penerbit Fakultas Ekonomi Universitas Indonesia.

Sunar Prasetyono, Dwi. 2007. Seni Kreatif Lobi dan Negosiasi, Merancang Kiat-Kiat Sukses Lobi dan Negosiasi Untuk Segala Kepentingan Anda (Dari Bisnis, Karir hingga Politik), Yogyakarta: Penerbit Think

Sundari, Tuti Upi dan La Rose. 1999. Pandangan Perempuan Tentang Indonesia Baru. Jakarta: yayasan La Rose

Verdiansyah, D. 2004. Pengantar Ilmu

Komunikasi. Jakarta: PT. Elex Media

Komputindo.

\section{Sumber-Sumber Lainnya:}

1.. http://dprd.jabarprov.go.id

2. m.viva.co.id (edisi 17 Juni 2016)

3. Kemlu.go.id (edisi 3 Agustus 2016)

4. www.cnnindonesia.com

5. www. news.okezone.com (edisi 29 Agustus 2017)

6. www.kompasiana.com (edisi 2 Juni 2017)

7. www.nasional.sindonews.com (edisi 18 Februari 2018) 